\title{
SURVEI PASAR ONLINE: STRATEGI RISET PASAR UNTUK MENGEMBANGKAN USAHA MIKRO WANITA di KELURAHAN PEKAN LABUHAN KECAMATAN MEDAN LABUHAN
}

\author{
Audia Junita $^{1^{*}}$, Iman Indrafana Kusumo Hasbulla², Muhammad Fauzan Azhmy ${ }^{3}$ \\ Fakultas Ekonomi Bisnis, Universitas Harapan Medan, Sumatera Utara, Indonesia \\ * Penulis Korespodensi : audia.junita@yahoo.com
}

\begin{abstract}
Abstrak
Kegiatan pengabdian pada masyarakat yang dilakukan pada pengusaha mikro di Kelurahan Pekan Labuhan Kecamatan Medan Labuhan bertujuan untuk memberikan pemahaman tentang pentingnya survey pasar dalam menjalankan usaha dan secara spesifik memberikan pengetahuan dan ketrampilan teknis cara membuat kuesioner online dan melakukan survei online ke pasar. Metode yang dipakai adalah ceramah (penyuluhan) dan praktik (pelatihan) menggunakan Handphone (HP) untuk membuat kuesioner online dengan aplikasi Google Form. Hasil kegiatan penyuluhan dan pelatihan terkait survei pasar online sebagai strategi pengembangan usaha mikro di Kelurahan Pekan Labuhan Kecamatan Medan Labuhan relatif efektif untuk merubah persepsi dan ketrampilan pengusaha dalam memanfaatkan survey pasar online melalui pembuatan kuesioner online dengan bantuan google form. Dominasi pengusaha mikro yang sebelumnya kurang memahami arti penting survei pasar sekaligus bagaimana melakukan survei pasar dengan bantuan teknologi secara online menjadi tercerahkan melalui kegiatan ini. Bahkan pengusaha mikro wanita memiliki minat besar untuk memanfaatkan ketrampilan dan ilmu yang diperoleh secara praktis guna memberikan hasil yang lebih baik bagi perkembangan usaha mereka.
\end{abstract}

Kata kunci: Survei Pasar Online, Kuesioner Online, Pengusaha Mikro

\begin{abstract}
Community service activities carried out at micro-entrepreneurs in Kelurahan Pekan Labuhan Medan Labuhan District aim to provide an understanding of the importance of marketing research in running a business and specifically provide knowledge and technical skills on how to create online questionnaires and conduct online surveys for business consumers. The method used is a lecture (counseling) and practice (training) using a handphone (HP) to create an online questionnaire with the Google Form application. Counseling and training activities related to online market surveys as a micro-business development strategy in Pekan Labuhan Sub-District Medan Labuhan Sub-District is relatively effective in changing entrepreneurs' perceptions and skills in utilizing online market surveys through the creation of online questionnaires with the help of Google forms. The dominance of micro-entrepreneurs who previously did not understand the importance of market research as well as how to conduct market surveys with the help of online technology became enlightened through this activity. Even the interests of large micro entrepreneurs to utilize the skills and knowledge gained practically to provide better results for their business development.
\end{abstract}

Keywords: Online Market Survey, Online Questionnaires, Micro-Enterpreneurs

\section{PENDAHULUAN}

Usaha mikro merupakan aset ekonomi penting dalam Negara. Usaha mikro berpotensi sebagai penyemai pembangunan ekonomi baik di Negara maju maupun berkembang (Dumitriu et al., 2019; Mujahid \& Noman, 2018). Usaha mikro dipertimbangkan sebagai determinan utama untuk pertumbuhan ekonomi, inovasi, peluang pekerjaan, dan kebertahanan hidup usaha rumah tangga di masyarakat. Usaha mikro diyakini memiliki fleksibilitas dan kemampuan beradaptasi tinggi dalam situasi krisis ekonomi. 
Namun banyak usaha mikro yang terhambat untuk tumbuh dan berfungsi secara efektif karena ketidakmampuan mengadopsi dan mamanfaatkan teknologi informasi padahal berbagai hasil riset membuktikan bahwa usaha mikro dapat berkembang melalui adopsi teknologi informasi. Temuan membuktikan bahwa melalui intervensi teknologi informasi maka pengusaha mikro diberdayakan secara psikologis melalui pengembangan keterampilan dan kesadaran kritis yang memungkinkan mereka terlibat dalam proses pengembangan bisnis (Kamal, 2009; Qureshil et al., 2009; Taiminen \& Karjaluoto, 2015; Setiowati et al., 2015; Sukanya \& Prakash, 2015; Foroudi et al., 2017; Dumitriu et al., 2019).

Usaha mikro di sebuah wilayah tidak cukup hanya sekedar muncul dalam jumlah yang banyak namun juga harus berkembang dengan mengadopsi perkembangan dalam situasi eksternal seiring dengan perkembangan waktu. Salah satu kegiatan penting dalam mengembangkan usaha mikro dengan memanfaatkan teknologi digital adalah riset pemasaran (Matko et al., 2014; Taiminen \& Karjaluoto, 2015; Burns \& Bush, 2017; Colombelli et al., 2016; Hague et al., 2016; Malhotra et al., 2017). Strategi pemasaran perusahaan bisnis mengalami evolusi dari waktu ke waktu sejalan dengan berkembangnya kemajuan teknologi. Saat ini dicirikan dengan era pemasaran digital. Pemasaran bukan hanya tentang produk dan orang, akan tetapi juga teknologi.

Dari perspektif pemasaran, teknologi informasi menjadi menarik ketika keberadaannya dapat dimanfaatkan untuk menghubungkan pemasar dan konsumen secara lebih efektif dan efisien. Teknologi informasi memiliki kemampuan untuk membuka peluang pasar baru (inovativitas) dan secara radikal 'mengguncang' pasar yang telah ada (Colombelli et al., 2016), meningkatkan pertumbuhan dan daya saing (Qureshil et al., 2009; Sukanya \& Prakash, 2015), meningkatkan kapabilitas pemasaran dan kinerja usaha kecil (Setiowati et al., 2015; Foroudi et al., 2017). Saat ini konsumen menjadi pihak yang lebih menguasai informasi, terhubung satu sama lain dengan lebih baik, lebih komunikatif dan memegang kendali dibandingkan sebelumnya (pemasaran tradisional) (Ryan \& Jones, 2009) sehingga berbagai upaya untuk inovasi usaha yang pengetahuannya bersumber dari pihak eksternal sangat penting diupayakan oleh pengusaha mikro (Lefebvre et al., 2015).

Dalam ekonomi digital, aspek waktu, perbedaan geografi, lokasi dan jarak ruang toko fisik menjadi tidak relevan lagi. Konsumen dapat memuaskan kebutuhan mereka dengan lebih cepat, mudah, murah dan relatif sedikit hambatan. Karenanya pemasar ditantang untuk mau dan mampu mengubah pendekatan pemasaran yang berbasis teknologi baik dalam pemasaran produk usaha maupun sebagai media untuk mendapatkan berbagai informasi pasar yang penting untuk mengambil keputusan pemasaran yang tepat (riset pasar).

Riset pasar dilakukan dengan berbagai tujuan penting antara lain dapat mengeksplorasi tingkat penerimaan pasar atas kualitas produk yang dipasarkan utamanya dari segmen dan target pasar tertentu (Clow \& James, 2014). Berbagai informasi tekait penerimaan pasar atas produk yang dipasarkan dapat diperoleh dari kegiatan riset pasar. Berbagai metode dapat dipilih pengusaha untuk melakukan riset pasar. Survei adalah salah satu metode yang relatif efektif dan efisien dilakukan karena dapat menjangkau cakupan pasar yang luas. Kemajuan teknologi digital dapat digunakan untuk memfasilitasi melakukan survei online (Brace, 2008). Terutama pada saat ini fasilitas untuk melakukan survei online semakin mudah walaupun belum semua pengusaha berminat dan memiliki pengetahuan yang cukup akan hal tersebut.

Kegiatan riset pasar penting dilakukan oleh para wirausaha wanita di Kelurahan Pekan Labuhan Kecamatan Medan Labuhan agar berkembang usahanya lebih baik lagi. Kecamatan Medan Labuhan merupakan daerah pesisir, salah satu dari 21 kecamatan yang ada dalam wilayah Pemerintah Kota Medan. Kecamatan Medan Labuhan merupakan kecamatan dengan wilayah terluas di Kota Medan yaitu sebesar $36,67 \mathrm{~km} 2$ atau mengambil porsi $13,83 \%$ dari seluruh luas wilayah Kota Medan sebesar 265,10 km2 (Badan Pusat Statistik Kota Medan, 2019). Kecamatan Medan Labuhan meliputi 6 (enam) kelurahan (Badan Pusat Statistik Kota Medan, 2018). Bila dibandingkan jumlah penduduk dengan luas wilayahnya, maka dalam Kecamatan Medan Labuhan, Kelurahan Pekan Labuhan merupakan kelurahan yang memiliki penduduk terpadat yaitu sebanyak 7.755 jiwa per km2. Berdasarkan kelompok umur, penduduk di Kecamatan Medan Labuhan didominasi oleh penduduk dengan usia 15-44 tahun dan jenis kelamin perempuan. Jumlah penduduk Medan Labuhan sebanyak 139.480 penduduk terdiri dari 64.744 orang laki-laki dan 74.736 perempuan (Badan Pusat Statistik Kota Medan, 2018). Komposisi mata pencaharian penduduk di Kecamatan Medan Labuhan didominasi oleh aktivitas lain-lain $(69,48 \%)$, pedagang $(11,27 \%$, dan nelayan $(11,02 \%)$. Beragam aktivitas usaha dilakukan masyarakat antara lain usaha mikro/rumah tangga yang dijalankan umumnya oleh ibu-ibu rumah tangga (Badan Pusat Statistik Kota Medan, 2018). Dengan demikian 
gambaran umum karakteristik penduduk di Kecamatan Medan Labuhan didominasi oleh pekerja usia produktif berjenis kelamin wanita.

Kondisi ini juga mewakili gambaran ketenagakerjaan di Kota Medan dimana pengangguran terbuka perempuan lebih kecil (36.165 orang) dibandingkan laki-laki (55.588 orang) (Badan Pusat Statistik Kota Medan, 2019). Di Kecamatan Medan Labuhan, dominasi pekerjaan yang dilakukan oleh pekerja wanita adalah sebagai pedagang dan wirausaha (Badan Pusat Statistik Kota Medan, 2018). Industri kecil, sedang dan menengah berkembang dengan baik di Kecamatan Medan Labuhan (https://pemkomedan.go.id/halmedan-labuhan.html, 2014). Wirausaha menjadi pilihan bekerja para pekerja perempuan untuk meningkatkan pendapatan rumah tangga. Kecenderungan semakin banyaknya pekerja perempuan di sektor publik semakin tampak seiring dengan perkembangan globalisasi yang ikut mengubah tata nilai dan budaya di masyarakat.

Berbagai riset terdahulu membuktikan kontribusi penting wanita dalam menjalankan kegiatan wirausaha (Cohoon et al., 2010; ITU, 2013; Azmat, 2013) baik di negara-negara maju maupun berkembang (Maradi \& Dasar, 2013; Malyadri, 2014; Watson et al., 2014; Putnam, 2019). Wirausaha menjadi pilihan bagi wanita dalam beraktivitas guna mendapatkan penghasilan untuk memenuhi kebutuhan sendiri sekaligus membantu keluarga (Frank, 2011).

Namun, pengusaha mikro wanita membutuhkan penguasaan berbagai kompetensi kewirausahaan yang dapat mendukung kinerja usaha, antara lain kompetensi dalam memanfaatkan teknologi informasi dalam menunjang kelancaran proses bisnis (Zizile \& Tendai, 2018). Orser et al. (2019) melalui risetnya mengungkapkan bahwa penguasaan Teknologi, Informasi dan Komunikasi (TIK) pada wirausaha mikro perempuan menjadi salah satu penghambat keunggulan kompetitif usaha. Kurangnya kesadaran akan manfaat TIK, terbatasnya peluang mendapatkan pelatihan, memunculkan penguasaan pengetahuan dan kompetensi yang terbatas pada wirusaha perempuan dibandingkan pria. Berdasarkan riset diketahui bahwa 94\% wirausaha wanita belajar sendiri (otodidak) menguasai TIK, $46 \%$ menerima pendidikan formal dan mendapatkan sertifikat, dan hanya sekitar $20 \%$ wirausaha mikro wanita belajar menggunakan teknologi digital melalui keterlibatan mentor (Orser et al., 2019). Pemanfaatan teknologi digital yang relatif sederhana dlam menjalankan bisnis seperti dengan menggunakan handphone, terbukti berkontribusi signifikan untuk meningkatkan efisiensi dan memaksimumkan keunggulan kompetitif bisnis (Ammar, 2017; Ameen \& Willis, 2016). Berdasarkan temuan-temuan tersebut, Orser et al. (2019) dan Ameen \& Willis (2016) menyarankan pentingnya diberikan pendampingan untuk meningkatkan penguasaan TIK kepada wirausaha mikro wanita, yang difasilitasi oleh pemerintah dan dilakukan oleh pihak ketiga, antara lain universitas yang memiliki penuguasaan pengetahuan dan teknolgi yang lebih baik.

Beberapa permasalahan mitra diidentifikasi berdasarkan wawancara pendahuluan terhadap beberapa pengusaha mikro di kelurahan Pekan Labuhan Kecamatan Medan Labuhan Kota Medan. Padahal para pengusaha mikro wanita tersebut memiliki gadget (Handphone) dan terbiasa menggunakan teknologi, namun terbatas sebagai alat komunikasi dan belum dimanfaatkan untuk melakukan riset pemasaran khususnya survei online. Para pengusaha mikro wanita di daerah tersebut sudah melakukan kegiatan riset pasar, namun belum intensif dan masih dilakukan secara sederhana serta manual secara spontan dengan konsumen yang ditemui. Pengusaha mikro wanita di Kelurahan Pekan Labuhan Kecamatan Medan Labuhan masih memiliki pengetahuan yang terbatas tentang pentingnya riset pemasaran. Teknis cara mendesain kuesioner, menginput, mendistribusikan dan merekapitulasi hasil penyebaran kuesioner dengan berbasis metode online masih belum familiar bagi pengusaha mikro. Padahal saat ini eranya technology-based. Relatif hampir semua kegiatan usaha telah beralih dari paper-based ke online-based.

Uraian latar belakang tersebut menjadi dasar kuat (urgent) untuk dilakukannya kegiatan pengabdian pada masyarakat di Kelurahan Pekan Labuhan Kecamatan Medan Labuhan terkait dengan riset pasar online sebagai strategi pengembangan usaha mikro pengusaha wanita di daerah tersebut. Kegiatan ini merupakan bentuk penyempurnaan dari riset pasar yang dilakukan para wirausaha wanita di Kelurahan Pekan Labuhan Kecamatan Medan Labuhan selama ini dengan caracara yang sederhana, manual dan insidentil. Kegiatan pengabdian pada masyarakat bertema riset pasar online sebagai strategi pengembangan usaha mikro pengusaha wanita bertujuan untuk membuka wawasan pengusaha mikro wanita di lokasi sasaran akan pentingnya riset pasar untuk pengembangan usaha. Kegiatan riset pasar dapat dilakukan dengan efisien dan efektif secara online dengan memanfaatkan alat teknologi informasi yang relatif sederhana yang sudah dimiliki oleh para wirausaha wanita. Pada kegiatan tersebut juga secara teknis para pengusaha mikro wanita dilatih 
ketrampilannya untuk membuat kuesioner online sebagai dasar untuk melakukan survei pasar online. Diharapkan melalui kegiatan pengabdian pada masyarakat ini, usaha mikro yang dikelola ibu-ibu rumah tangga di Kelurahan Pekan Labuhan Kecamatan Medan Labuhan menjadi lebih kompetitif dan menjadi salah satu sector yang dapat berkontribusi penting untuk menghidupkan perekonomian masyarakat di daerah tersebut

\section{METODE}

Data yang ditampilkan dalam artikel ini berasal dari kegiatan penyuluhan dan pelatihan teknis terkait topik survei pasar online sebagai strategi riset pasar untk mengembangkan usaha mikro wanita di Kelurahan Pekan Labuhan Kecamatan Medan Labuhan. Sebanyak 30 pengusaha mikro wanita di Kelurahan Pekan Labuhan Kecamatan Medan Labuhan menjadi peserta penyuluhan dan pelatihan. Data yang dikumpulkan dalam kegiatan tersebut dianalisis dengan menggunakan statistic deskriptif dengan bantuan aplikasi Statistical Package for the Social Sciences (SPSS).

Rincian langkah-langkah yang dilakukan dalam kegiatan pengabdian pada masyarakat di Kelurahan Pekan Labuhan Kecamatan Medan Labuhan sebagai berikut :

1. Sebelum diberikan diseminasi pengetahuan tentang pentingnya survei pasar dan pelatihan untuk membuat kuesioner online, terlebih dahulu tingkat pengetahuan pengusaha mikro di Kelurahan Pekan Labuhan diukur dengan melakukan tes awal (pre test) dengan menyebarkan kuesioner manual (hard copy). Peserta pengabdian pada masyarakat diminta ntuk mengisi kuesioner tersebut sebelum pemaparan dilakukan oleh tim peneliti. Sebanyak 6 item pertanyaan kuesioner pada pre test disebarkan secara manual kepada peserta.

2. Memberikan materi penyuluhan terkait ruang lingkup riset pemasaran dan pentingnya melakukan hal tersebut. Salah satu cara yang dapat dipilih untuk menjalankan riset pemasaran adalah dengan melakukan survei online. Penyampaian matari dilakukan dengan menggunakan software power point, infocus dan LCD.

3. Membuat draft kuesioner yang akan diinput ke dalam aplikasi survei online (Google Form).

4. Memberikan pelatihan teknis cara membuat akun google, membuat kuesioner online dengan Gogle Form, menginput daftar pertanyaan, cara merevisi pertanyaan, menambahkan fitur-fitur yang menarik dan cara mendistribusikan kuesioner online tersebut. Peserta diminta untuk secara langsung menggunakan Handphone (HP) masing-masing untuk praktik membuat kuesioner online.

5. Peserta juga diberikan pelatihan bagaimana cara merekapitulasi hasil penyebaran kuesioner online untuk dianalisis dan diambil kebijakan yang tepat berorientasi pada pengembangan usaha.

6. Di akhir sesi, para peserta diminta kesediaannya untuk mengisi kuesioner post test secara online agar dapat memberikan gambararan terkait tingkat pemahaman peserta atas topik yang disampaikan setelah mereka mendapatkan materi penyuluhan dan pelatihan. Sebanyak 6 item pertanyaan kuesioner post test disebarkan secara online melalui link yang telah dibuat untuk diisi oleh setiap peserta.

\section{HASIL DAN PEMBAHASAN}

Profil pengusaha mikro wanita dapat dideskripsikan dari dimensi usia, tingkat pendidikan akhir, jenis usaha, jumlah pekerja dan tahun memulai usaha mikro. Berdasarkan usia, pengusaha mikro wanita di Kelurahan Pekan Labuhan Kecamatan Medan Labuhan didominasi oleh usia 36-45 Tahun $(61,1 \%)$ kemudian diikuti oleh pengusaha berusia mapan yaitu di atas 45 Tahun $(27,8 \%)$. Hanya sebagian kecil pengusaha mikro berusia relatif muda yaitu di bawah 25 Tahun $(5,6 \%)$ dan berusia 26-35 Tahun (5,6\%). Jika dikaitkan dengan pengalaman menjalankan usaha yang diukur dari tahun memulai usaha, mayoritas pengusaha mikro wanita di Kelurahan Pekan Labuhan Kecamatan Medan Labuhan memulai usaha dalam 5 tahun terakhir yaitu di atas tahun 2015 (50\%) diikuti dengan pengusaha yang sudah relatif lama menjalankan usaha yaitu dalam rentang tahun 2000 hingga 2010 sebesar 38,9\%.

Berdasarkan tingkat pendidikan akhir, pengusaha mikro wanita yang menjadi responden kegiatan pengabdian pada masyarakat di Kelurahan Pekan Labuhan Kecamatan Medan Labuhan didominasi oleh pengusaha mikro dengan tingkat pendidikan menengah atas yaitu SMA dan atau SMK $(61,1 \%)$, diikuti dengan tingkat pendidikan menengah pertama $(22,2 \%)$ dan tingkat pendidikan tinggi $(16,7 \%)$. Jenis usaha yang dijalankan oleh pengusaha mikro wanita di Kelurahan Pekan Labuhan Kecamatan Medan Labuhan didominasi oleh usaha makanan $(77,8 \%)$ dikuti dengan usaha pakaian $(22,2 \%)$. Dalam menjalankan usaha, pengusaha mikro di Kelurahan Pekan Labuhan Kecamatan Medan Labuhan membutuhkan tenaga kerja. Jumlah tenaga kerja yang dipekerjakan bervariasi. Mayoritas pengusaha mikro mempekerjakan tenaga kerja 1-2 orang $(66,7 \%)$ dan hanya $33,3 \%$ yang memiliki tenaga kerja di atas 2 orang. Dengan demikian tepat jika pengusaha wanita di Kelurahan 
Pekan Labuhan Kecamatan Medan Labuhan masuk dalam kategori pengusaha mikro.

Hasil pengumpulan data pre test menunjukkan bahwa mayoritas pengusaha mikro di Kelurahan Pekan Labuhan Kecamatan Medan Labuhan masih kurang memiliki pengetahuan yang cukup $(55,6 \%)$ tentang kegiatan survei pasar. Hanya sebanyak 44,4\% menyatakan mereka mengetahui tentang kegiatan survei pasar (Gambar 1).

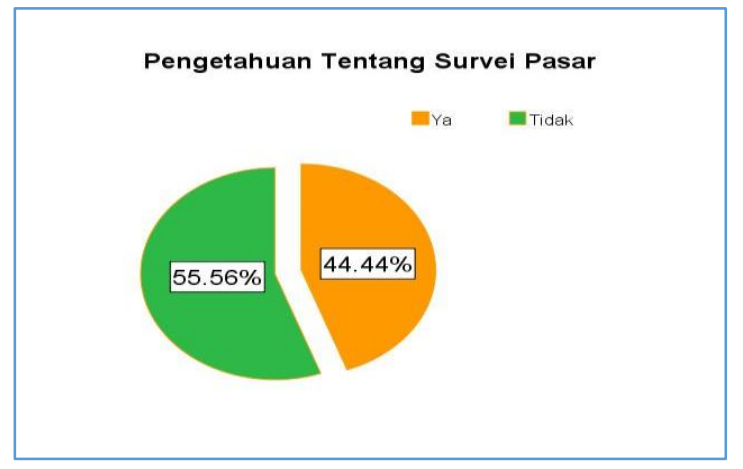

Gambar 1. Pengetahuan Tentang Survei Pasar

Namun sekalipun pengusaha mikro di Kelurahan Pekan Labuhan Kecamatan Medan Labuhan masih kurang memiliki pengetahuan yang cukup $(55,6 \%)$ tentang kegiatan survei pasar, mereka merasa kegiatan tersebut penting untuk dilakukan. Gambar 2 menunjukkan data bahwa sebesar $88,89 \%$ pengusahan mikro wanita merasa penting untuk mendapat masukan dari konsumen, dan hanya sebesar $11,1 \%$ merasa tidak penting.

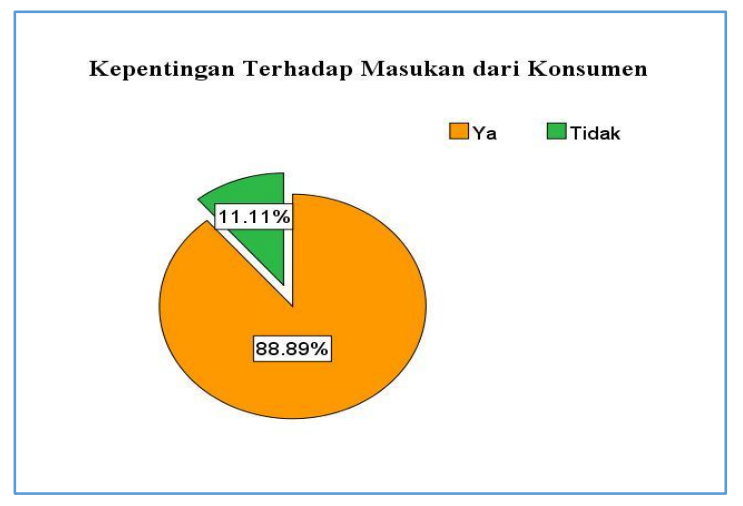

Gambar 2. Kepentingan Melakukan Kegiatan Survei Pasar

Terkait frekuensi melakukan kegiatan survei pasar, sebagian $(50 \%)$ pengusaha mikro di Kelurahan Pekan Labuhan Kecamatan Medan Labuhan menyatakan pernah melakukan kegiatan tersebut sedangkan sebagian lainnya tidak pernah melakukan sama sekali (Gambar 3).

Dari $50 \%$ pengusaha mikro yang melakukan survei pasar (Gambar 3), berbagai cara yang dilakukan antara lain tampak pada Gambar 4. Sebanyak 16,67\% mengamati langsung tren pasar, sebanyak 5,56\% memantau langsung perkembangan harga di pasar, sebanyak 22,22\% menanyakan secara langsung kepada teman-temannya berbagai kekurangan atas produk yang dijual, sebanyak 5,56\% memanfaatkan media sosial whats-up dan instagram untuk mendapatkan masukan dari pasar.

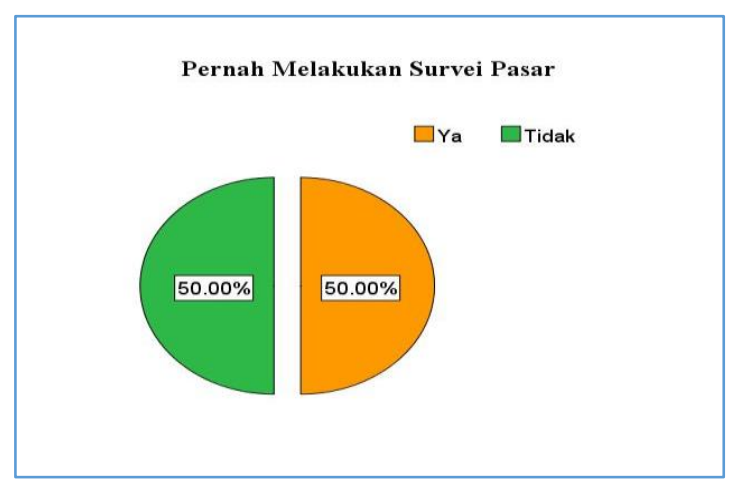

\section{Gambar 3. Persentase Melakukan Kegiatan Survei Pasar}

Dari berbagai pilihan cara melakukan survei pasar yang dilakukan selama ini (Gambar 4), belum ada yang melakukan survei dengan menyebarkan kuesioner secara online. Pengusaha mikro di Kelurahan Pekan Labuhan Kecamatan Medan Labuhan baru sebagian yang paham bahwa kegiatan survei pasar dapat dilakukan secara lebih efektif dan efisien dengan menggunakan bantuan alat teknologi yang sederhana seperti handphone.

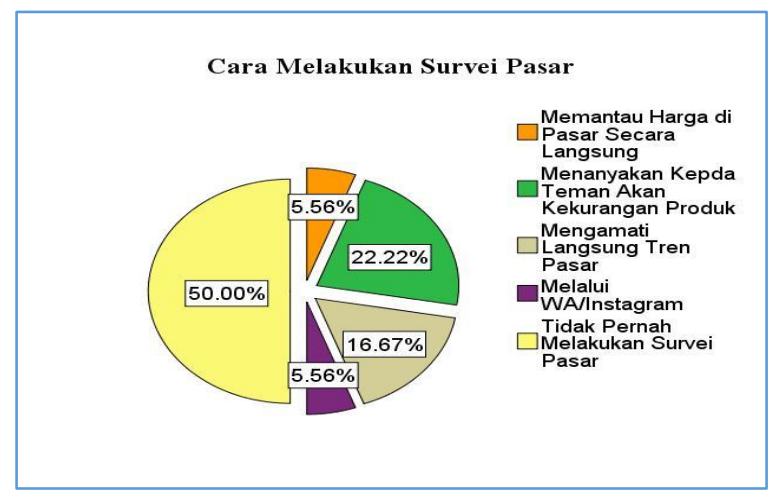

Gambar 4. Cara Pengusaha Mikro Melakukan Survei Pasar 
Mayoritas pengusaha mikro di Kelurahan Pekan Labuhan Kecamatan Medan Labuhan masih tidak paham bahwa menyebarkan kuesioner adalah satu metode kegiatan survei pasar yang dapat digunakan untuk mengetahui kelemahan produk sekaligus mengembangkan usaha $(55,6 \%)$. Hanya sebesar $44,4 \%$ yang paham mengenai hal tersebut (Gambar 5).

Demikian pula pemahaman pengusaha mikro di Kelurahan Pekan Labuhan Kecamatan Medan Labuhan tentang cara membuat kuesioner dengan media online. Mayoritas pengusaha mikro tidak paham cara membuat kuesioner online $(77,8 \%)$ dan hanya sebesar $22,2 \%$ yang memahami hal tersebut (Gambar 6).

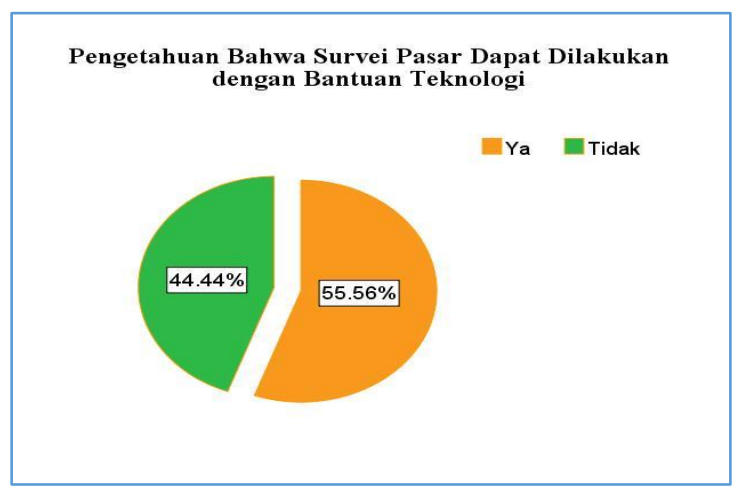

Gambar 5. Pengetahuan Survei Pasar Dapat Dilakukan Dengan Teknologi

Dengan demikian kegiatan penyuluhan untuk meningkatkan pemahaman pengusaha kecil akan pentingnya survei pasar diiringi dengan pelatihan untuk membuat kuesioner online penting dilakukan dan menjadi kebutuhan penting para pengusaha mikro wanita di Kelurahan Pekan Labuhan Kecamatan Medan Labuhan.

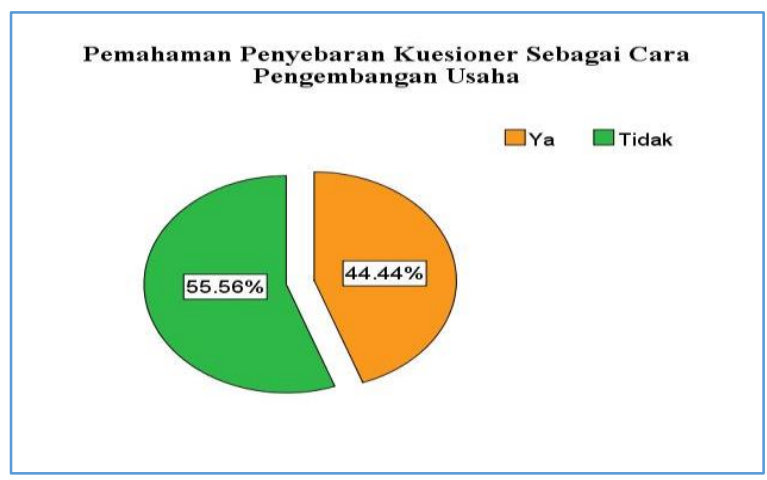

Gambar 6. Pemahaman Membuat Kuesioner Online

Menyikap hasil pre test, selanjutnya tim memberikan penyuluhan tentang pentingnya survei pasar online sebagai bagian dari kegiatan riset pasar. Penyuluhan dilakukan dengan memaparkan materi yang bersifat teoritis terkait pengertian umum riset pasar sebagai materi pendahuluan. Pengusaha mikro wanita diberikan wawasan makna penting kegiatan riset pasar bagi mereka, tidak hanya untuk memahami kebutuhan dan keluhan kosumen akan tetapi juga untuk melakukan evaluasi dan menyusun strategi pemasaran baru (predicting). Berbagai metode riset pasar disampaikan kepada peserta kegiatan pengabdian pada masyarakat beserta kelebihan dan kelemahan masing-masing. Kuesioner adalah salah satu metode yang dinilai paling efektif dan efisien untuk mengjangkau cakupan pasar yang luas. Dengan bantuan alat teknologi komunikasi sederhana (handphone) maka kegiatan survey pasar online dapat dilakukan secara praktis.

Kegiatan penyuluhan selanjutnya diikuti dengan pelatihan praktis (short course) mengenai cara membuat kuesioner online dengan bantuan google form kepada para pengusaha mikro wanita di Kelurahan Pekan Labuhan Kecamatan Medan Labuhan Kegiatan pelatihan tersebut disampaikan secara rinci, disertai dengan coaching dari tim dan Tanya jawab dengan peserta, untuk memastikan semua peserta benar-benar mendapatkan pemahaman yang baik atas materi pelatihan.

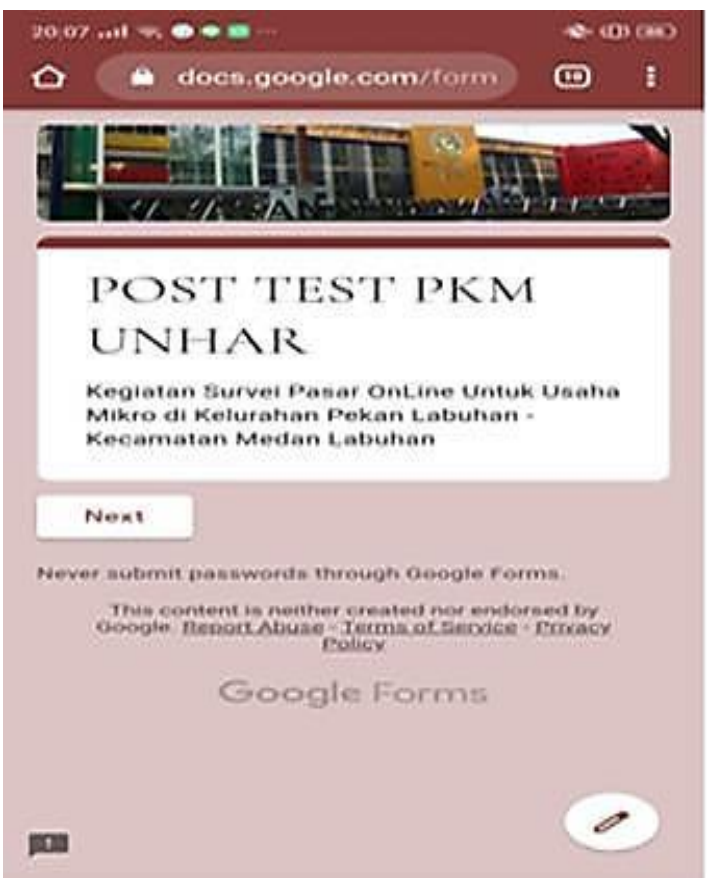

Gambar 8. Tampilan Kuesioner Online

Setelah kegiatan pelatihan dan couching selesai dilakukan, selanjutnya tim kegiatan pengabdian pada masyarakat mendistribusikan link 
http://bit.ly/Post.Test_Pekan_Labuhan kepada para peserta pengabdian pada masyarakat yaitu para pengusaha mikro wanita di Kelurahan Pekan Labuhan Kecamatan Medan Labuhan untuk mengisi kuesioner post test secara online. Kuesioner post test online disebarkan untuk mengukur pemahaman para pengusaha mikro di Kelurahan Pekan Labuhan Kecamatan Medan Labuhan atas materi yang diberikan oleh tim pengabdian pada masyarakat sekaligus pemahaman mereka dalam menggunakan kuesioner online. Dalam hal ini peserta dianalogikan layaknya konsumen yang diminta untuk mengisi kuesioner online mengenai efektivitas atas kegiatan penyuluhan dan pelatihan yang disampaikan oleh tim. Tampilan kuesioner online adalah sebagaimana tampak pada Gambar 8.

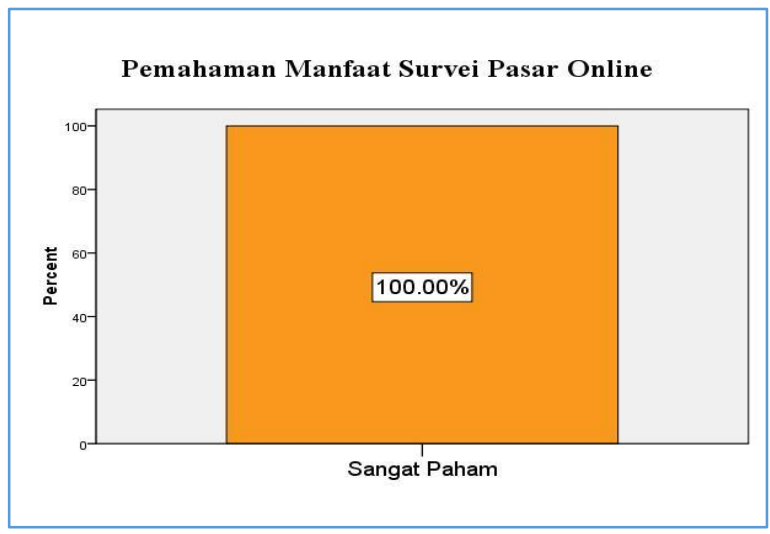

Gambar 9. Pemahaman Manfaat Survei Online

Dari hasil analisa data kuesioner post test diketahui bahwa pemahaman para pengusaha mikro di Kelurahan Pekan Labuhan Kecamatan Medan Labuhan meningkat dari sebelum diberikan penyuluhan dan pelatihan. Seluruh peserta memahami manfaat dari melakukan survei pasar online (100\%) sebagai salah satu metode penting untuk mengembangkan usaha yang dijalankan selama ini (Gambar 9).

Pengusaha mikro di Kelurahan Pekan Labuhan Kecamatan Medan Labuhan juga meningkat kepentingannya untuk melakukan kegiatan survei online untuk mengembangkan usaha. Mayoritas merasa sangat penting (778\%) dan penting $(22,2 \%)$ untuk melakukan kegiatan tersebut (Gambar 10).

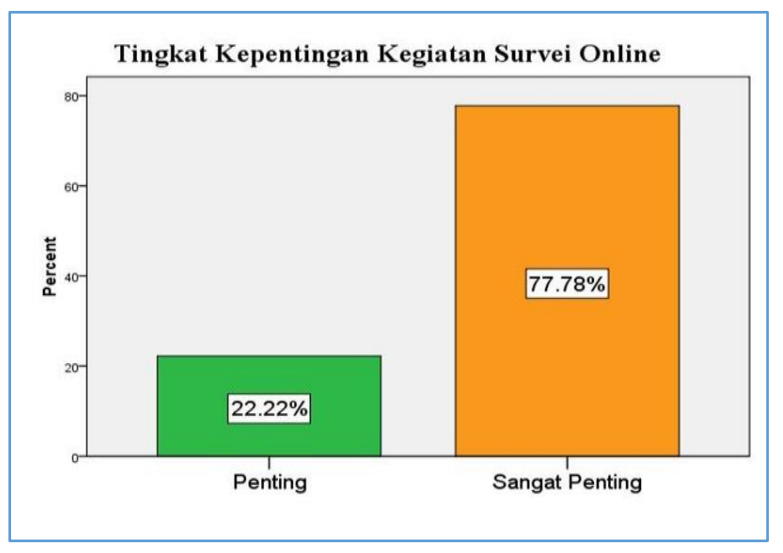

Gambar 10. Kepentingan Melakukan Kegiatan Survei Online

Para pengusaha mikro di Kelurahan Pekan Labuhan Kecamatan Medan Labuhan tidak hanya merasa penting namun juga seluruhnya berminat (100\%) untuk melakukan kegiatan survei pasar online sebagai strategi pengembangan usaha yang relatif efektif dan efisien di jaman sekarang (Gambar 11).

\section{Minat Untuk Melakukan Survei Pasar Online}

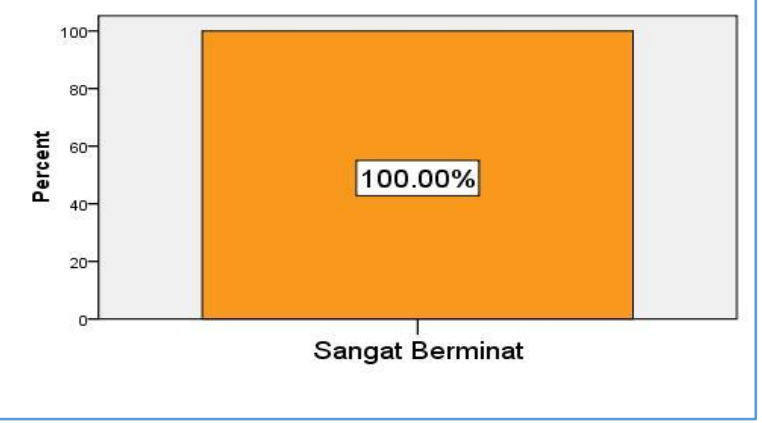

Gambar 11. Minat Melakukan Kegiatan Survei Online

Mayoritas pengusaha mikro di Kelurahan Pekan Labuhan Kecamatan Medan Labuhan merasa mudah dan efisien menggunakan fitur kuesioner online dengan menggunakan google form dibandingkan harus menyebarkan kuesioner secara tatap muka. Sebanyak 94,4\% pengusaha mikro di Kelurahan Pekan Labuhan Kecamatan Medan Labuhan sangat mudah dan 5,6\% merasa agak mudah menggunakan fitur kuesioner online melalui gadget yang dimiliki (Gambar 12). 


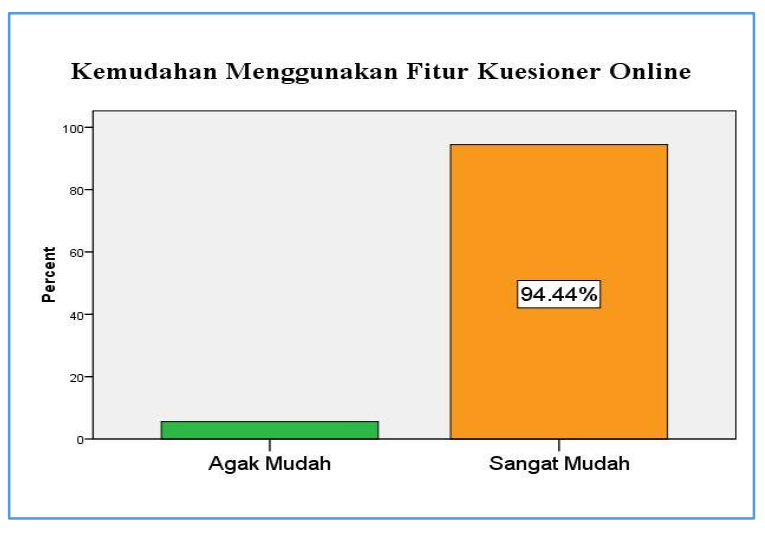

Gambar 12. Kemudahan Menggunakan Fitur Kuesioner Online

Setelah mengikuti kegiatan penyuluhan dan pelatihan survei pasar online maka para pengusaha mikro di Kelurahan Pekan Labuhan Kecamatan Medan Labuhan meningkat kemampuannya untuk membuat kuesioner online. Sebanyak $94,4 \%$ peserta marasa mampu memuat kuesioner online dan hanya sebesar 5,6\% yang masih merasa kurang mampu melakukan hal tersebut (Gambar 13).

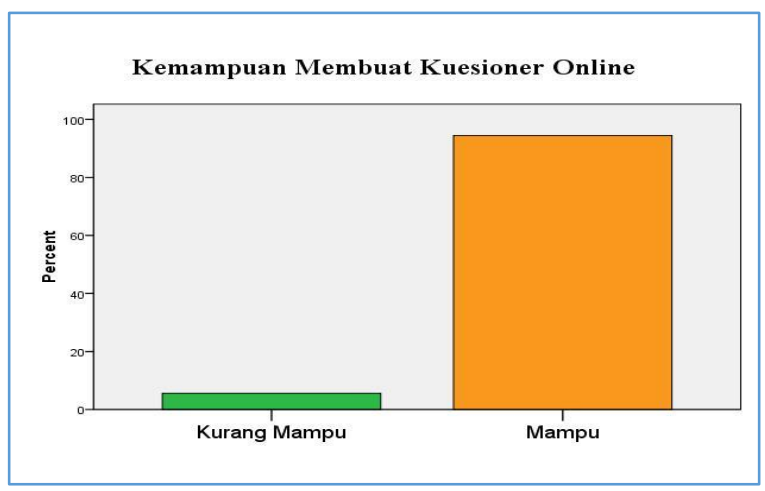

Gambar 13. Kemampuan Membuat Kuesioner Online

Dengan meningkatnya kemampuan para pengusaha mikro wanita di Kelurahan Pekan Labuhan Kecamatan Medan Labuhan membuat kuesioner online, muncul keinginan kuat dari peserta selanjutnya memanfaatkan kuesioner online dalam menjalan usaha. Berbagai informasi yang diperoleh dari menyebarkan kuesioner online diharapkan dapat memberikan banyak informasi penting untuk digunakan oleh para pengusaha mikro wanita melakukan perbaikan dan mengembangkan usaha di masa melalui penyebaran kuesioner secara online yang informasinya dapat digunakan untuk mengembangkan usaha di masa yang akan datang. Seluruh peserta berkeinginan untuk memanfaatkan fitur kuesioner online untuk mengembangkan usaha $(100 \%)$ (Gambar 14).
Hasil riset membuktikan bahwa kebaradaan motivasi intrinsik dalamdiwi wirausaha secara signifikan terkait erat dengan intensi penggunaan internet dalam proses bisnis berorientasi pasar (Caniëls, et al., 2015). Selanjutya adopsi teknologi informasi dan komunikasi pada usaha mikro, kecil dan menengah khususnya handphone berimplikasi positif tidak hanya meningkatkan efisiensi biaya dan meningkatkan pelayanan kepada para pelanggan (Kamal, 2009; Setiowati et al., 2015; Ameen \&Willis, 2016; Ammar, 2017), namun juga dapat meningkatkan kinerja usaha dan kreativitas pengusaha melalui penemuan berbagai ide baru sekaligus upaya pengembangan solusi baru untuk memenuhi harapan pasar (Lefebvre et al., 2015; Balan, 2017).

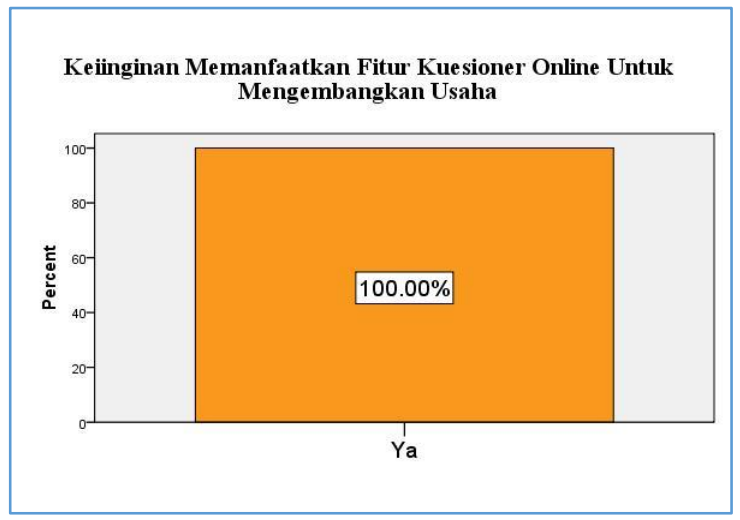

Gambar 14. Keinginan Memanfaatkan Kuesioner Online untuk Mengembangkan Usaha

\section{KESIMPULAN}

Kegiatan penyuluhan dan pelatihan terkait survei pasar online sebagai strategi pengembangan usaha mikro di Kelurahan Pekan Labuhan Kecamatan Medan Labuhan relatif efektif untuk merubah persepsi dan ketrampilan pengusaha dalam memanfaatkan survei pasar online melalui pembuatan kuesioner online dengan bantuan google form. Dominasi pengusaha mikro yang sebelumnya kurang memahami arti penting riset pasar sekaligus bagaimana melakukan survei pasar dengan bantuan teknologi secara online menjadi tercerahkan melalui kegiatan ini. Bahkan minat pengusaha mikro besar untuk memanfaatkan ketrampilan dan ilmu yang diperoleh secara praktis guna memberikan hasil yang lebih baik bagi perkembangan usaha.

Namun, kegiatan sejenis tidak cukup hanya sekali diberikan kepada para pengusaha mikro di Kelurahan Pekan Labuhan Kecamatan Medan Labuhan. Pembaharuan pengetahuan dan inovativitas pengusaha untuk adopsi teknologi informasi dan komunikasi harus berkesinambungan dilakukan. Tidak hanya terkait survei pasar namun juga berbagai kegiatan manajerial 
lainnya yang dapat lebih efektif dan efisien digunakan dengan berbasis teknologi. Selaras dengan desakan dan tuntutan lingkungan eksternal akan hal tersebut. Intervensi institusional untuk meningkatkan pertumbuhan usaha mikro melalui pemberian bantuan keuangan, regulasi, infrastruktur dari berbagai agen pemerintah dibutuhkan khususnya bagi usaha start-ups di berbagai wilayah. Koordinasi dan sikronisasi berbagai program pemerintah diperlukan sebagai dukungan penting bagi para pengusaha mikro.

\section{UCAPAN TERIMA KASIH}

Terima kasih kepada aparat kelurahan Pekan Labuhan Kecamatan Medan Labuhan atas fasilitasi yang diberikan sehingga kegiatan pengabdian pada masyarakat dapat berjalan dengan baik. Demikian pula kepada Lembaga Penelitian dan Pengabdian Pada Masyarakat Universitas Harapan Medan atas bantuan pendanaan yang diberikan.

\section{DAFTAR PUSTAKA}

Ammar, A. A. (2017), Factors Influencing Intention to Adopt Mobile Banking in Sudanese Microfinance Sector. Dissertations, Multimedia University, Malaysia.

Badan Pusat Statistik Kota Medan. (2018). Kecamatan Medan Labuhan dalam Angka. Badan Pusat Statistik Kota Medan, Medan

Ameen, N.A., \& Willis, R. (2016). The Use of Mobile Phones to Support Women's Entrepreneurship in Tthe Arab Countries. International Journal of Gender and Entrepreneurship, 8(4), 424-445. DOI:10.1108/IJGE-10-2015-0037.

Azmat, F. (2013). Opportunities or Obstacles? Understanding Challenges Faced by Migrant Women Entrepreneurs. International Journal of Gender and Entrepreneurship, 5(2), 198-215.

Badan Pusat Statistik Kota Medan. (2019). Kota Medan dalam Angka. Badan Pusat Statistik Kota Medan, Medan.

Balan, C. (2017). Online Platforms: Emerging Trends in The Open in The Open Innovation for SMES. Quality-Access to Success, 18(S3), 31-41.

Brace, I. (2008). Questionnaire Design: How to Plan, Structure and Write Survey Material for Effective Market Research. Second Edition. Kogan Page Limited, United Kingdom.

Burns, A. C., Veeck, A., \& Bush, R. F. (2017). Marketing Research. Eighth Edition. Pearson Education Limited, United Kingdom.

Caniëls, M. C. J., Lenaerts, H. K. L. , \& Gelderman, C. J. (2015). Explaining The internet Usage of SMEs: The Impact of Market Orientation, Behavioural Norms, Motivation and Technology
Acceptance. Internet Research, 25(3), 358-377. DOI: $10.1108 /$ IntR-12-2013-0266.

Clow, K. E. \& James, K. E. (2014). Essentials of Marketing Research: Putting Research into Practice. SAGE Publications, Inc., California.

Cohoon, J., Wadhwa, V., \& Mitchell, L. (2010). The Anatomy of an Entrepreneur are Successful Women Entrepreneurs Different from Men?, available

at: www.kauffman.org//.../successful women entr epreneurs_510.pdf (accessed 11 July 2020).

Colombelli, A., Krafft, J., \& Vivarelli, M. (2016). To Be Born is Not Enough: The Key Role of Innovative Start-Ups. Small Bus Econ, 47, 277 291. DOI: $10.1007 / \mathrm{s} 11187-016-9716-y$.

Dumitriu, D., Militaru, G., Deselnicu, D. C., Niculescu, A., \& Popescu, M. A. (2019). A Perspective Over Modern SMEs: Managing Brand Equity, Growth and Sustainability Through Digital Marketing Tools and Techniques. Sustainability, 11, 1-24. DOI:10.3390/su11072111.

Franck, A. (2011). Factors Motivating Women's Informal Micro- Entrepreneurship. International Journal of Gender and Entrepreneurship, 4(1), 65-78.

Foroudi, P., Gupta, S., Nazarian, A., Duda, M. (2017). Digital Technology and Marketing Management Capability: Achieving Growth in SMEs. Qualitative Market Research: An International Journal, 20(2), 230-246. DOI: 10.1108/QMR01-2017-0014.

Hague, P., Harrison, M., Cupman, J. \& Truman, O. (2016). Market Research in Practice: an Introduction to Gaining Greater Market Insight. Third Edition. Kogan Page Limited, USA.

ITU. (2013). Doubling Digital Opportunities: Enhancing the Inclusion of Women and Girls in the Information Society, available at: www.eldis.org/go/home\&id66023\&typeDocum ent\#.VYbIQIfH_IU (accessed 12 Juny 2020).

Kamal, M. (2009). Effects of Information Technology Interventions in Microenterprises on Development. Dissertation, University of Nebraska, USA.

Lefebvre, V. M., Steur, H. D., \& Gellynck, X. (2015). External Sources for Innovation in Food SMEs. British Food Journal, 117(1), 412-430. DOI: 10.1108/BFJ-09-2013-0276.

Malhotra, N. K., Nunan, D. \& Birks, D. F. (2017). Marketing Research: an Applied Approach. Fifth Edition. Pearson Education Limited, United Kingdom.

Malyadri, G. (2014). Role of Women Entrepreneurs in The Economic Development of India. Indian Journal of Research, 3(3), 104-105. 
Maradi, M., \& Dasar, P. (2013). The Strategic Role of Women Entrepreneurship with Reference to Indian Economy: Hurdles and Empowerment. Global Journal of Commerce and Management Perspective, 2(1), 62-66.

Mujahid, N., \& Noman, M. (2018). The Impact of SMEs on the Economic Development of Pakistan. Pakistan Perspectives, 23(2), 81-94.

Matko, A., Szucs, E., Takacs, T., \& Kovacs, S. (2014). Examining The Significance of Start-Ups. Int. Rev. Appl. Sci. Eng., 5 (2), 181-190. DOI: 10.1556/IRASE.5.2014.2.11.

Orser, B., Riding, A., \& Li, Y. (2019). Technology Adoption and Gender-Inclusive Entrepreneurship Education and Training. International Journal of Gender and Entrepreneurship, 11(3) 273-298. DOI:10.1108/IJGE-02-2019-0026.

Putnam, K. A. (2019). ICT Usage among Afghan Women Business Leaders: A Descriptive Case Study, Dissertation, University of Phoenix.

Ryan, D. \& Jones, C. (2009). Understanding Digital Marketing: Marketing Strategies for Engaging The Digital Generation. Kogan Page Limited, United States.

Setiowati, R., Hartoyo, Daryanto, H. K., Arifin, B. (2015). The Effects of ICT Adoption on Marketing Capabilities and Business Performance of Indonesian SMEs in The Fashion Industry. Journal of Business and Retail Management Research (JBRMR), 100-115.

Sukanya, M. \& Prakash, R. K. (2015). IT Penetration in Micro, Small and Medium Enterprises. Journal of Rural and Industrial Development, 3(1), 8-11.

Taiminen, H. M. \& Karjaluoto, H. (2015). The Usage of Digital Marketing Channels in SMEs. Journal of Small Business and Enterprise Development, 22(4), 633-651. DOI: 10.1108/JSBED-05-20130073 .

Qureshil, S., Kamal, M., \& Wolcott, P. (2009). Information Technology Interventions for Growth and Competitiveness in MicroEnterprises. International Journal of E-Business Research, 5(1), 117-140.

Watson, J., Gatewood, E., \& Lewis, K. (2014). A Framework for Assessing Entrepreneurial Outcomes: an international Perspective. International Journal of Gender and Entrepreneurship, 6(1), 2-14.

Zizile, T. \& Tendai, C. (2018). The Importance of Entrepreneurial Competencies On The Performance of Women Entrepreneurs In South Africa. Journal of Applied Business Research,
$34(2)$,

DOI:10.19030/jabr.v34i2.10122

https://pemkomedan.go.id/hal-medan-labuhan.html, Medan Labuhan, 20 Februari 2014. 